\section{Neisseria gonorrhoeae resistance test against cefixime in gonorrhea patients in Surabaya}

\author{
Amalia Rositawati, Sawitri, \\ Afif Nurul Hidayati
}

Department of Dermatology and Venereology, Faculty of Medicine, Universitas Airlangga, Dr. Soetomo General Hospital/Universitas Airlangga Hospital, Surabaya, Indonesia

\begin{abstract}
Gonorrhea remains as one of the most common sexually transmitted diseases in developing countries. The third generation cephalosporin such as cefixime is now one of the first-line therapies in many regions. Over the last decade, strains of Neisseria gonorrhoeae have been reported to develop high levels of resistance against several antimicrobial agent cefixime. The purpose of this study is to evaluate the susceptibility of cefixime to Neisseria gonorrhoeae. The study design was descriptive laboratory observational cross sectional from June 2017 to September 2017. Twenty isolates Neisserria gonorrhoeae taken from outpatients with positive complaints of purulent secretions, who visited 7 Community Health Centre in Surabaya and met the inclusion criterias, were tested with cefixime diffusion susceptibility test. 7 of 20 isolates $(35 \%)$ were resistant to cefixime and 13 of 20 isolates $(65 \%)$ sensitive to cefixime. Neisseria gonorhoeae strain was proven to be resistant to cefixime by performing diffusion test.
\end{abstract}

\section{Introduction}

Gonorrhea is caused by the bacterium Neisserria gonorrhoeae, which is a gram negative bacterium and anaerobic facultative, and characterized by the presence of muco-purulent secretion from urethra. Gonorrhea is generally transmitted through sexual contact with an incubation period of 2-5 days. However, Gonorrhea may also be transmitted to the fetus at the time of delivery. All susceptible age groups are infected with this disease, but their highest incidence is at age $15-35$ years. ${ }^{1,2}$

Gonorrhea is one of the second most common sexually transmitted infections worldwide. The incidence of Gonorrhea is increasing every year. According to the World Health Organization (WHO), it is estimated that 62 million new cases found each year. In the United States, based on data from The Centers for Disease Control and Prevention (CDC), approximately 333,004 cases of Gonorrhea were reported in 2013 and this disease is estimated to attack about 820,000 people every year. ${ }^{3,4}$ Based on data from Surabaya City Health Office, the total gonorrhea patients in all health centers in Surabaya in 2016 was 289 patients. The incidence of gonorrhea in Dr. Soetomo Hospotal Surabaya in the period of 5 years (2002-2006) there were 321 $(0.94 \%)$ new gonorrhhea patients from total patient visits of 34,274 in the Outpatient Unit of Dr. Soetomo Hospital Surabaya, and $52.6 \%$ of those gonorrhea patients were found to be in productive age group (age 25-44 years $).^{5}$

Based on a study of cefixime susceptibility to $N$. gonoeehoeae diffusion conducted to female sexual workers (FSW) with uncomplicated gonorrhea cervicitis, the incidence of gonorrhea in sex workers (FSW) reported at Putat Jaya Public Health Center Surabaya there were 213 new cases in $2011 .{ }^{6}$ Based on data of patient visit at Dr. Soetomo Hospital Oupatient Clinic Surabaya in 2013 there were 3 patients, 8 patients in 2014, 20 patients in 2015 and 37 patients in 2016.

The tendency of resistance to $N$. gonorrhoeae is classified into three eras namely pre-Quinolone era, Quinolone era, and postQuinolone era. The pre-Quinolone era is characterized by the use of sulfonamides, tetracyclines, chloramphenicol, erythromycin and penicillin. The Quinolone era is characterized by the use of quinolone derivatives as a treatment option. The postQuinolone era is characterized by the use of a third-generation cephalosporin as an option. ${ }^{?}$

Neisseria gonorrhoeae resistance rates to antibiotics are currently increasing rapidly. Gonorrhea resistance rates against penicillin, tetracycline, and quinolone groups are also increasing, so these drug classes are not recommended as gonorrhea therapy in some countries in the world. Gonorrhea resistance to oral third-generation cephalosporin therapy has been found in many countries. ${ }^{4,8}$ In 2002 The Centers for Disease Control and Prevention (CDC) and WHO (World Health Organitation) recommended uncomplicated gonorrhea treatment with cephalosporin groups cefixime $400 \mathrm{mg}$ orally or ceftriaxone $125 \mathrm{mg}$ intramuscular (IM). The CDC, in 2010, recommended dual therapies for gonorrhea with cephalosporin and either Azithromycin or Doxycycline due to an increase in $N$. gonorrhoeae resistance to fluroquinolone, including ciprofloxacin. In recent years there has
Correspondence: Afif Nurul Hidayati, Department of Dermatology and Venereology, Faculty of Medicine, Universitas Airlangga, Dr. Soetomo General Hospital/Universitas Airlangga Hospital, Surabaya, Indonesia. Tel.: +628123028024

E-mail: afif_nurulhidayati@fk.unair.ac.id

Key words: cefixime, diffusion susceptibility test, Neisseria gonorhoeae.

Contributions: the authors contributed equally.

Conflict of interest: The authors of this work, hereby declare that there is no competing interest among them and that there are also no financial or professional affiliations with any group or company.

Received for publication: 1 February 2019. Accepted for publication: 13 February 2019.

This work is licensed under a Creative Commons Attribution-NonCommercial 4.0 International License (CC BY-NC 4.0).

(C) Copyright A. Rositawati et al., 2019

Licensee PAGEPress, Italy

Dermatology Reports 2019; 11(s1):8060

doi:10.4081/dr.2019.8060

been report about a decrease in sensitivity to cefixime in gonorrhea cases as it was reported in Australia in 2010 and 3 cases of gonorrhea in homosexual groups in the UK and 1 patient in Austria in 2011.9,10 The sensitivity to cefixime has been reported to be decreased, as evidenced by the minimal increase inhibitory concentration (MIC) of cefixime in some cases of gonorrhea reported in Europe since 2010. ${ }^{10}$

Methods for sensitivity tests can be done with various techniques. The most commonly used method is to use diffusion discs and dilute the discs according to the Clinical Laboratory Standard Institute criteria, first described by Bauer et al. Another technique is a modification to the diffusion discs as per the National Committee for Clinical Laboratory Standards (NCLLS), this technique is called Etest. This Etest is then diluted using an antibiotic strip to be able to determine the minimal inhibitory concentration (MIC) values. The use of diffusion discs by the CLSI method is an efficient technique in countries with limited laboratory facilities, cheaper and can be readily applied to determine the inhibitory zone values of an antibiotic. ${ }^{11}$

A cefixime sensitivity test has been conducted on Neisseria gonorrhoeae at Puskesmas Putat Jaya Surabaya. In 3 months, 12 isolates of Neisseria gonorrhoeae were found from 68 Female Sex Worker (FSW) cervical secretions. The results showed that 3 of 12 isolates $(25 \%)$ 
were resistant to cefixime and 9 of 12 isolates $(75 \%)$ were sensitive to cefixime. ${ }^{12}$ The high resistance of gonorrhea to antibiotics can cause decreased cure rates and incomplete treatment of gonorrhea infected patents, Hence, these patients could potentially transmit already antibiotics resistance $N$. gonorrhoeae to others. ${ }^{12}$ The importance of treating gonorrhea infection in order to reduce the high prevalence of gonorrhea was the basis for conducting antibiotic resistance test studies against Neisseria gonorrhoeae. The benefits of this study are to contribute to the pattern of Neisseria gonorrhoeae resistance to some antibiotics in gonorrhea patients and to offer a recommendation in determining the treatment strategy of uncomplicated gonorrhea infection. Cefixime sensitivity antibiotic susceptibility studies with diffusion from uncomplicated gonorrhea patients in Surabaya have not been conducted and there is currently little data on the sensitivity and resistance of gonorrhea infection to antimicrobials. Therefore, sustained monitoring of $N$. gonorrhoeae antibiotics resistance is needed as part of prevention against the use of ineffective antibiotics in the treatment of gonorrhea infection.

Between 2007 and 2012, an antimicrobial susceptibility profile report and antimicrobial resistance (AMR) for antimicrobials in India showed a decrease in susceptibility to Ceftriaxone by $1.8 \%$ in 2008 , but increased significantly to $15.8 \%$ in 2010 . In the year of 2010 it was reported that 11 isolates with decreased susceptibility to ceftriaxone. During the study period, it also showed decreased susceptibility to cefixime and cefpodoxime. Of the 11 strains, 3 were resistant to penicillin, tetracycline, and ciprofloxacin and 7 resistant to penicillin and ciprofloxacin. None of these strains are resistant to azithromycin. ${ }^{3,4}$

\section{Materials and Methods}

This study was conducted in Surabaya from outpatients who visited 7 Community Health Centre. In patients who clinically met the inclusion criterias were diagnosed urethritis gonorrhoe, based on anamnesis, clinical examination, gram examination, positive culture, using Thayer Martin culture containing: vancomycin to suppress the growth of gram-positive bacteria, kolimestat to suppress the growth of gram-negative bacteria, nystatin to suppress the growth of fungi, trimethoprim to suppress the growth of Proteus spp, and incubated at $37^{\circ} \mathrm{C}$ for maximum 48 hours. In the culture the gonorrhea will appear as white gray colony, shiny and convex. Then the identification test of oxidase, catalase and fermentation was performed. For the sensitivity test against antibiotics diffuse discs was used by assessing the antibiotic inhibition zone based on Clinical Laboratory Standards Institute (CLSI) standard as shown on Table 1.

\section{Results}

In this study the distribution of gonorrhea infection by sex category resulted that gonorrhea infection was found more frequently in males with as many as 19 persons $(95 \%)$ than it was found in females with only 1 person $(5 \%)$. The distribution of gonorrhea infections by sex category can be seen in Table 2. Gonorrhea infection is more common to be found in the 15-25 age group with total of 11 persons (55\%) than the rest of the groups as follows: in the 26-35 age group 7 persons $(35 \%)$ and in the $36-55$ age group 2 persons $(10 \%)$. From 20 patients observed, it was found that 13 were heterosexual males $(65 \%), 6$ were Male have Sex with Male (MSM)(30\%) and 1 heterosexual female $(5 \%)$. Of the 20 patients, the number of sexual partners they had in the last 1 week were that 11 people had 1-5 sexual partners $(55 \%), 5$ people had 6-10 sexual partners $(25 \%), 1$ person had 11-15 sexual partners $(5 \%)$ and 3 people had more than 15 sexual partners $(15 \%)$. From education background perspective, high school education background contributed the most patients with 11 persons (55\%) The complete education level of the patients is as follows: the primary school education background 4 persons (20\%)junior high school background 3 persons (15\%), high school background 11 persons and university education background 2 persons $(10 \%)$. In this study, patients who had self-medication were as many as 11 people $(55 \%)$, as oppose to those who never had self treatment 9 persons $(45 \%)$. The type of antibiotics taken were Combipack (Cefixime + Azithromycin) by 2 persons (10\%) tetracycline by 2 persons (10\%), amoxicillin by 2 persons $(10 \%)$, thiamphenicol by 1 person $(5 \%)$, ampicillin by 3 persons $(15 \%)$, ofloxacin by 1 person $(5 \%)$. In this study, gonorrhea patients who had a history of HIV were 2 people (10\%), had no history of HIV were 4 people $(20 \%)$ and who had not been tested for HIV were 14 people $(70 \%)$. The results of Neisseria gonorrhoeae's resistance percentage to antibiotics in gonorrhea infected patients found that 7 of 20 isolates $(35 \%)$ were resistant to cefixime and 13 of 20 isolates $(65 \%)$ sensitive to cefixime (Figure 1). Of the 7 isolates $(35 \%)$ resistant to cefixime, 3 isolates $(15 \%)$ had a $6 \mathrm{~mm}$ inhibition zone, 1 isolate $(5 \%)$ with a $25 \mathrm{~mm}$ inhibition zone, 1 isolate $(5 \%)$ with a $26 \mathrm{~mm}$ inhibitory zone, 1 isolate (5\%) with a $29 \mathrm{~mm}$ inhibition zone, and 1 isolate (5\%) with a $30 \mathrm{~mm}$ inhibition zone, whereas from 13 isolates $(65 \%)$ sensitive to cefixime, 2 isolates $(10 \%)$ had a $31 \mathrm{~mm}$ inhibition zone, 1 isolate (5\%) with $32 \mathrm{~mm}$ inhibition zone, 1 isolate $(5 \%)$ with $34 \mathrm{~mm}$ inhibition zone, 1 isolate (5\%) with $35 \mathrm{~mm}$ inhibition zone, 4 isolates (20\%) with 36 $\mathrm{mm}$ inhibition zone, 2 isolates $(10 \%)$ with $38 \mathrm{~mm}$ inhibition zone, 1 isolate $(5 \%)$ with $40 \mathrm{~mm}$ inhibition zone, and 1 isolate $(5 \%)$ with $46 \mathrm{~mm}$ inhibition zone.

\section{Discussion}

This study used 20 isolates of Neisseria gonorrhoeae that had been cultured. There

Table 1. Antibiotics Resistance and Sensitivity Criterias based on Clinical Laboratory Standard Institute (CLSI) 2015.,

\begin{tabular}{llllllll} 
Agent & $\begin{array}{l}\text { Diffusion } \\
\text { disc }\end{array}$ & \multicolumn{3}{c}{$\begin{array}{c}\text { Inhibition } \\
\text { diameter(mm) }\end{array}$} & Zone MIC (g/mL) & \\
& & S & I & R & S & I & R \\
Ceftriaxone & $30 \mathrm{~g}$ & $\geq 35$ & - & - & $\leq 0,25$ & - & - \\
Cefixime & $5 \mathrm{~g}$ & $\geq 31$ & - & - & $\leq 0,25$ & - & - \\
\hline Tetracycline & $30 \mathrm{~g}$ & $\geq 38$ & $31-37$ & $\leq 30$ & $\leq 0,25$ & $0,5-1$ & $\geq 2$ \\
Azithromycin & $15 \mathrm{~g}$ & $\geq 25$ & - & - & $\leq 0,12$ & - & - \\
\hline
\end{tabular}

Table 2. Sample Distribution by Gender.

\begin{tabular}{lcc} 
Gender & Total & Percentage \\
Males & 19 & $95 \%$ \\
Females & 1 & $5 \%$ \\
\hline Total & 20 & $100 \%$ \\
\hline
\end{tabular}


was a growth of colonies, and identified to be Neisseria gonorrhoeae through biochemical examination. These isolates were obtained from research and subjected to meet the inclusion and exclusion criteria. The distribution of Neisseria gonorrhoeae by sex in this study was found more in males with as many as 19 people (95\%) than in females with only 1 person $(5 \%)$. One of the reasons why more samples were acquired in from males was because 7 Community Health Centres in Surabaya, from where all the samples were taken from, were more visited by MSM (Males have Sex with Males) patients who are required to come every month for sexually transmitted infections screening, besides the symptoms of gonorrhoeae in women can be asymptomatic so they don't go to a health center.

Distribution of Neisseria gonorrhoeae based on sexual orientation risk factor in this study resulted that heterosexual men was the highest risk factor with as many as 13 people $(65 \%)$, MSM with 6 people $(30 \%)$ and heterosexual women with only 1 person (5\%). According to data from the Integrated Biological and Behavior Surveillance from several cities in Indonesia in 2013, the highest prevalence percentage of gonorrhea infection was in direct risk factor for FSW (female sexual worker) by $34.8 \%$, for MSM by $21.2 \%$ and for high-risk men by $8.5 \%{ }^{2}$

Distribution of age is also important to note, this is because the younger the person, the more susceptible that person to infected by STIs. In male age group 20-34 years and female aged group 16-24 years are considered high risk to be infected sexually transmitted diseases. In adolescent girls, the susceptible to STIs is due to immature reproductive organ cells. The younger the FSW age group the higher the prevalence of sexually transmitted infections. ${ }^{\text {? }}$

Based on this study, Neisseria gonorrhoeae distribution based on age showed that age group $15-25$ years $(55 \%)$, with as many as 11 people, was the highest age group for Neisseria gonorrhoeae infection This was followed by age group 26-35 years with as many as 7 people (35\%) and group age $36-55$ years with as many as 2 people $(10 \%)$. This is similar to the study by Wang et al., (2013) which concluded that people with Neisseria gonorrhoeae were most found in the age group 15-25 years. Research by Swan and colleagues (2013) also reported that $23.9 \%$ of patients aged 25 to 29 were infected with gonorrhea. This age group percentage is greater than those with age $>30$ years. ${ }^{13,14}$

Education can bring one's insight or knowledge about this matter. In general, a highly educated person will have more knowledge than a person with a lower level of education, especially knowledge of sexually transmitted infections and their effects. Based on this research, Neisseria gonorrhoeae distribution based on education level showed that as many as 4 people $(20 \%)$ had primary education, $3(15 \%)$ had mid secondary education, 11 (55\%) had secondary education and only $2(10 \%)$ had tertiary education level. The cross sectional study conducted from Female Sex Workers (FSW) in Thailand found that gonorrhea infection was found more in FSW with education level of mid secondary or lower by $31 \%$ compared to those with secondary level by $16 \%$. Meanwhile, studies in Cambodia reported that FSW with low level education got infected with gonorrhea 26.2 times to those high level of education. ${ }^{15}$

The level of education will also affect the knowledge, attitudes and behavior of people infected with gonorrhea in having a safer sex, selecting and using antibiotics. This factor will encourage some patients to seek their own treatment and repeat the occurrence of gonorrhea infection, and hence affects the occurrence of resistance that causes the disease to not heal. From the research conducted by Sutama (2005) on 63

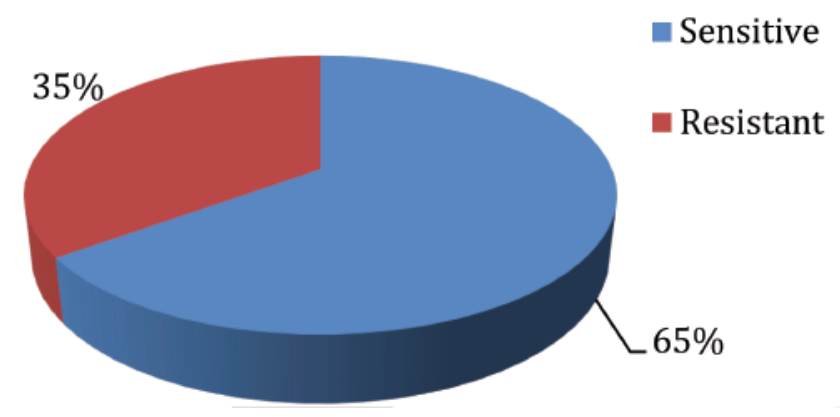

Figure 1. Percentage of Neisseria gonorrboeae resistance cefixime.

(FSW) in Yogyakarta, 30\% of the FSWs had mid secondary education level and 54\% of the FSW had primary education level. ${ }^{16}$ This difference in education background implicated the FSW's level of understanding and knowledge. $84 \%$ of the FSWs knew gonorrhea not from education but through conversations among fellow FSWs and counsel with volunteers and clinic doctors. About $26 \%$ of the FSWs bought their own antibiotics at drugstores and or pharmacies, and only about $30 \%$ of them knew how to properly use antibiotics. According to research conducted in Bali on STI patients who sought treatment from private doctors, 1613 of 2834 people $(56.9 \%)$ managed to cure their own diseases. Among the antibiotics purchased $50 \%$ were "Supertetra" and $17 \%$ amoxicillin $(85 \%)$. The way patients obtained the antibiotics were from pharmacies as many as 958 people $(59.4 \%)$, from drugstore 355 people $(22.0 \%)$, from stalls 154 people $(9.5 \%)$; from others 146 people $(9.1 \%){ }^{17}$

In this study, gonorrhea patients with a history of self-treatment were 11 people (55\%). Commonly used antibiotics were tetracycline 2 people (10\%), amoxicillin 2 people $(10 \%)$, thiamphenicol 1 person (5\%), ampicillin 3 person $(15 \%)$ and Ofloxacin 1 person $(5 \%)$. The places where the gonorrhea patients got the medicines were from the pharmacy 12 people $(30 \%)$ from drug store 4 people $(20 \%)$, from stalls 2 people $(10 \%)$, others 4 people $(20 \%)$.

Gonorrhea as well as some other genital diseases can cause CD4 lymphocytes (T helper lymphocytes) clustered in the infected site to fight infection. CD4 is the main target of HIV, this causes people infected with gonorrhea to be more easily contracted with HIV. Sexually transmitted infections are cofactors that facilitate the transmission of HIV so that people are more vulnerable to HIV, or in other words STIs will facilitate the transmission of HIV. In this study, the distribution of gonorrhea patients with a history of HIV infection was 2 people (10\%). The STBP data of 2013 showed that $10.16 \%$ of FSW were HIV-infected, while $89.84 \%$ had not been detected for HIV antibodies in their blood. ${ }^{18}$ Another study by Julia $\mathrm{M}$ et al., in Arizona mentions the distribution of gonorrhea infection accompanied by a history of HIV infection obtained in $54,9 \%$ of the samples. ${ }^{19}$

As reported by the Centers for Disease Control and Prevention, criterias for resistance to cefixime have not been clearly defined. Cefixime sensitivity to Neisseria gonorrhoeae is called sensitive if the inhibition zone is $>31 \mathrm{~mm}$ by using diffusion test and $\mathrm{MIC}<0.25 \mu \mathrm{g} / \mathrm{mL}$ dilution. This is in accordance with 2015 
Clinical Laboratory Standard Institute (CLSI) criteria. 7 of 20 isolates $(35 \%)$ experienced a decrease in susceptibility to cefixime and 13 of 20 isolates $(65 \%)$ did not. In agreement with Astindari's research that was conducted on FSW in Surabaya in 2015 , 9 out of 12 isolates $(75 \%)$ were sensitive to cefixime. 4 of the 9 isolates $(44.5 \%)$ that were sensitive to cefixime had a inhibition zone with a diameter of $31 \mathrm{~mm}$, which was the limit of cefixime ability to inhibit the growth of Neiseeria gonorrhoeae. ${ }^{6}$

Factors that influence gonorrhea resistance to cefixime, according to research by Cole $\mathrm{M}$ et al., (2014), are risk factors for MSM..$^{20}$ As stated in the research by Wang et al., (2013), the most susceptible isolates occurred in FSW were 17 isolates $(77.8 \%) .{ }^{13}$ Likewise, studies in the UK in 2013 found a higher sensitivity to cefixime obtained in FSW than that found in heterosexual men and MSM. ${ }^{11}$ FSW and MSM are easier to be exposed to STIs because sexual behavior such as having multiple sex partners. FSW is often asymptomatic, gonorrhea infection escapes diagnosis, resulting in complications so that the infection becomes heavier, cannot be completely resolved and can cause resistance. ${ }^{11}$

Unemo et al stated that penA mosaic, mtrR and penB could cause Neisseria resistance. gonorrhoeae against cefixime. ${ }^{12}$ Ohnishi et al (2014) stated that the molecular mechanisms that cause Neisseria gonorrhoeae resistance to cefixime occur due to the formation of mosaic penA-X encoding penicillin binding protein 2 (PBP2) and chromosomal mutations to form a new variant of penA-X. PenA gene mosaic, which encodes PBPs-2, will reduce the binding capacity of penicillin and cephalosporins, which in turn will cause resistance or decreased sensitivity to cefixime. ${ }^{21}$

\section{Conclusions}

Neisseria gonorhoeae strain was found to be resistant to cefixime by performing diffusion test. It is recommended that further research, such as dillution test, be conducted to obtain further results of the Neisseria gonorhoeae's increasing resistence to cefixime

\section{References}

1. Daili SF. Gonore. Dalam: Daili SF, Makes WI, Zubeir F, editor. Infeksi menular seksual, edisi ke-4, Jakarta: FKUI; 2009: 65-76.

2. Hakim L. Epidemiologi infeksi menular seksual. Dalam: Daili SF, Makes WI, Zubier F, Judanarso J, editor. Infeksi menular seksual, edisi ke-4, Jakarta: FKUI; 2009: 3-16.

3. Centers for Disease Control and Prevention. Sexualy Transmitted Disease Treatment Guidelines. Gonococcal Isolate Surveillance Project (GISP). 2015. [cited 21 November 2016] Availabe from:URL: http:/www.dcd.gov/std/tg2015/Gonore. html.

4. Centers for Disease Control and Prevention. Antibiotic-Resistant Gonore. 2015. [cited 21 November 2016]. Availabe from:URL: http:/www. cdc.gov/std/Gonore/arg.html.

5. Jawas FA. Penderita gonore di Divisi Penyakit Menular Seksual Unit Rawat Jalan Penyakit Kulit dan Kelamin RSUD Dr. Soetomo Surabaya periode 2002-2006. BIKKK 2008;20(3):21728.

6. Astindari, Lumintang H, Setyaningrum T. Uji Difusi Sefiksim terhadap Neisseria gonorrhoeae pada Servisitis Gonore tanpa Komplikasi. Berkala Ilmu Kesehatan Kulit dan Kelamin. 2014; 26:134-8.

7. Latel, A.L., Chaundhry, U., Saluja, D. An Insight Into Drug Resistance Profile and Mechanism of Drug Resistance in Neisseria Gonorrhoeae. Indian J Med Res 2011. 134(4):419-31.

8. Bollen, L.J.M., Anartati, A.S., Morineau, G., Sulami, S., Prabawantu, C. and Silfanus, F.J. 2010. Addresing the high prevalence of gonorrhoeae and chlamydia among female sex workers in Indonesia: results of an enhanced, comprehensive intervention. Sex Trans Infect. 86: 61-5

9. Unemo, M., and Shafer W.M, Antimicrobial resistance in Neisseria Gonorrhoeae in the 21st Century: Past, evolution, and Future. Clin Microbiol Rev 2014. p. 587-613.

10. Centers for Disease Control and Prevention. Antibiotic-Resistant Gonore. 2015. [cited 16 November 2016]. Availabe from:URL: http:/www.cdc.gov/std/Gonore/arg.html

11. Barry, P.M., Klausner, J.D. The Use of Cephalosporins for Gonorrhoeae: The Impending Problem of Resistance. Expert Opin Pharmacother 2009.10(4):555-77.

12. Unemo M, Golparian D, Stary A, Eigentler A. First Neisseria gonor- rhoeae strain with resistance to Sefiksim causing gonorrhea treatment failure in Austria. Euro Surveill 2011;16(43):196-9

13. Wang Q, Chen X, Yin Y, Liang G, Jiang N, Liu Q, et al. The Prevalences of Neisseria gonorrhoeae and Chlamydia trachomatis infections among female sex worker in China. BMC Public Health. 2013;13:121.

14. Swan BK1, Tupper B, Sczyrba A, Lauro FM, Martinez-Garcia M, González JM, et al. Prevalent genome streamlining and latitudinal divergence of planktonic bacteria in the surface ocean. Proc Natl Acad Sci USA. 2013 Jul 9;110(28):11463-8.

15. Ellen S, Neth S, Jennifer E, Keo S, Melissa C, John K, et al. Sex work and HIV in Cambodia: trajectories of risk and disease in two cohorts of high-risk young women in Phnom Penh, Cambodia. Int J STD AIDS 2011; 16:170-4.

16. Sutama IM. Studi pemilihan dan penggunaan antibiotik di kalangan pekerja seks komersial di lokasi Pasar Kembang Yogyakarta tahun 2005. Tesis, Fakultas Farmasi Universitas Sanata Darma.

17. Desak MP. Uji resistensi Neisseria gonorrhoeae terhadap beberapa antibiotika pada penderita gonore tahun 2015 . Tesis, Program Pendidikan Dokter Spesialis Universitas Udayana.

18. HIV integrated biological and behavioral surveillance survey among the general population in Tanah Papua, Indonesia. STBP. 2013. [cited 20 Januari 2017]. Availabe from:URL: https://catalogue.nla.gov.au/Record/754 1160.

19. Julia M, Jana Distefano ,Jennifer Warrington, S. Robert Bailey, Michelle Winscott, Melanie M. Taylor. Trends in Reported Syphilis and Gonorrhea Among HIV-Infected People in Arizona: Implications for Prevention and Control. Public Health Rep. 2014 Jan-Feb; 129(Suppl 1): 85-94.

20. Cole M, Spiteri G, Town K, Unemo M, Hoffmann S, Chisholm S. Risk Factors for Antimicrobial-Resistant Neisseria gonorrhoeae in Europe. 2014: Vol 41:12.

21. Ohnisi, M., Golparian, D., Shimuyta, K., Saika, T., Hoshina, S., Iwasaku, K., Nakayama, S.C., Kitawaki, J. Unemo, M. Is Neisseria gonorrhoeae Initiating A Future Era of Untreatable Gonorrhea?: Detailed Characterization of the Fisrst Stain with High-Level Resistance to Ceftriaxone. Antimicrob Agent and Chemother 2011. p.3538- 45. 